\title{
The Superiority of Supercritical Fluid Extraction Over Steam Distillation and Solvent Extraction Methods for the Extraction of Aroma from Salacca zalacca (Gaertn.) Voss
}

\author{
NUR NADHIRAH, H. M., ${ }^{1}$ SITI ZAITON, M. S., ${ }^{1}$ JAMSHED, M. S., ${ }^{1}$ ZAIDUL, I. S. M., ${ }^{2}$ \\ MOKHLESUR, M. R., ${ }^{3}$ HAFIZAN JUAHIR, ${ }^{3 \star}$ TENGKU, M. A., ${ }^{4 *}$ WAN NIK, W. B., ${ }^{5}$ \\ and NURUL ISLAM, M. S. ${ }^{5}$
}

1Department of Pharmaceutical Chemistry, Kulliyyah of Pharmacy, International Islamic University Malaysia, 25200 Kuantan, Pahang, Malaysia.

${ }^{2}$ Department of Pharmaceutical Technology, Kulliyyah of Pharmacy, International Islamic University Malaysia, 25200 Kuantan, Pahang, Malaysia.

${ }^{3}$ East Coast Environmental Research Institute, Universiti Sultan Zainal Abidin, Gong Badak Campus, 21300 Kuala Terengganu, Terengganu, Malaysia.

${ }^{4}$ Faculty of Medicine, Universiti Sultan Zainal Abidin, 21300 Kuala Nerus, Terengganu, Malaysia.

${ }^{5}$ School of Ocean Engineering, University Malaysia Terengganu (UMT), 21030, Kuala Nerus, Terengganu, Malaysia.

*Corresponding author E-mail: dszaiton@iium.edu.my, mokrahman@ unisza.edu.my

http://dx.doi.org/10.13005/ojc/350607

(Received: October 07, 2019; Accepted: November 27, 2019)

\section{ABSTRACT}

Salacca zalacca (Gaertn.) Voss or snake fruit is a species of palm tree native to Southwest Java and North Sumatra in Indonesia. It is known as one of the exotic fruits in Malaysia. It has a pleasant pineapple, pear and banana-like aromas. Due to its pleasant aroma, Salacca zalacca has potential in the perfumery and pharmaceutical industries. New extraction techniques were introduced in this study to overcome conventional methods limitations such as supercritical fluid extraction (SFE). This technique is available to extract aroma of plants and it is rapidly gaining attention due to its superior benefits over the conventional extraction methods. In this study, the volatile aroma of Salacca zalacca was extracted by steam distillation, solvents extraction with hexane, diethyl ether and dichloromethane (DCM) and SFE. Carbon dioxide was the supercritical fluid for the SFE. The efficiency and percentage yield of these extracts were compared. The percentage Yields of SFE extracts were higher $\left(10 \mathrm{MPa}, 30^{\circ} \mathrm{C}: 0.2577 \% ; 25 \mathrm{MPa}, 30^{\circ} \mathrm{C}: 0.2375 \% ; 30 \mathrm{MPa}, 30^{\circ} \mathrm{C}: 0.2721 \%\right)$ than the steam distillation $(0.1855 \%)$, diethyl ether $(0.5692 \%)$, hexane $(0.0511 \%)$ and DCM $(0.1358 \%)$ solvent extracts. However, SFE produced a lower yield $\left(40 \mathrm{MPa}, 70^{\circ} \mathrm{C}: 0.2721 \%\right)$ than the diethyl ether solvent extraction $(0.5692 \%)$ but SFE was found to be more efficient and environmentally friendly.

Keywords: Supercritical fluid extraction, Steam distillation, Solvent extraction, Aroma.

\section{INTRODUCTION}

Salacca zalacca (Gaertn.) Voss is also known as salak fruit or "snake fruit" due to the appearance of the fruit's skin which resembles the structure and color of snake's skin. It is a species

This is an Open Access article licensed under a Creative Commons license: Attribution 4.0 International (CC- BY). Published by Oriental Scientific Publishing Company @ 2018

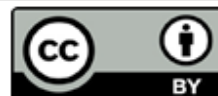


of palm tree (family Aracaceae) native to Java and Sumatra in Indonesia and is considered as an exotic fruit in Malaysia. The flesh usually consists of three white flesh lobes of similar sizes containing large inedible seeds. The fruit has a pleasant pineapple, pear and banana-like aromas and is usually eaten raw or made into pickle ${ }^{1}$. Despite its pleasant aroma, there was very limited study has been performed on extraction of volatile aroma of $S$. zalacca. The volatile aroma of $S$. zalacca may have potential in industries such as pharmaceuticals and perfumeries.

Volatile aroma is included in the volatile fraction framework together with headspace, essential oils, extracts prepared with specific techniques, flavor and fragrances ${ }^{2}$. Aromas are defined as volatile compounds that enter the nasal cavity, interact with the olfactory receptors and elicit a sensory response, often at low concentration ${ }^{3}$. Some factors may influence the volatile aroma compositions of a fruit. These factors are the genetic makeup, degree of maturity, part of plant in which the volatile aromas are isolated, variations in climate or growing regions, harvest times, postharvest handling, storage and extraction techniques ${ }^{4-5}$.

Previous studies showed that methyl esters of carboxylic acids were the most abundance compounds in the Salacca zalacca ${ }^{6-8}$. However, it must be emphasized that high concentration of certain volatile compounds do not necessarily mean that the compounds are the aroma impact compounds of the fruit; rather it is the odour threshold values of the different constituents that will determine the intensity of the overall aroma perceived ${ }^{9}$. Therefore, aroma impact compounds responsible for the characteristic odour of Salacca zalacca was investigated by Wijaya et al., (2005) ${ }^{7}$ which found that methyl 3-methyl-pentanoate (fruity, sweet, typical S. zalacca) and methyl 3-methylbutanoate (Salacca zalacca-like, cheesy typical Salacca zalacca) were responsible for the typical Salacca zalacca aroma.

Two conventional extraction methods used in this study were steam distillation and consecutive solvent extraction method. According to Chun-ping, Shanshan, Yuanshang, Ying, and Hui $(2016)^{10}$, steam distillation and organic solvent extraction were among the most widely used methods for the extraction of volatile oil from medicinal plants. Distillation of aromatic plants implies vaporizing or liberating the oils from the oil glands in the plant tissues in the presence of Steam distillation. It is the most widely accepted process to produce essential oil in large scale. It has become a standard practice in flavor and fragrance business, and in the food and pharmaceutical industries ${ }^{11}$.

For the consecutive solvent extraction method, the plant sample was cold macerated (soaked) in solvents of different polarities. Maceration is the simplest extraction technique dedicated to plant materials. It is particularly suitable for the extraction of volatile and thermally labile compounds due to its mild extraction conditions ${ }^{12}$.

With technological advancement, new techniques such as supercritical fluid extraction (SFE) method has been developed to speed up the extraction of solid plant materials ${ }^{12}$. SFE method is based on the solvating power of supercritical fluids which are influenced by pressure and temperature of extraction process ${ }^{13-14}$. Carbon dioxide is the most widely used supercritical fluid (SCF) and is considered as the solvent of choice in the extraction of natural products since it is cheap, non-toxic, non-flammable and non-polluting ${ }^{12-14}$.

There are a lot of advantages of SFE. SFE is a safe, clean and environmentally friendly processing technique which produces extracts of augmented quality and purity compared to the solvent extraction and steam or hydrodistillation method ${ }^{15}$. It has the ability to extract oil or desired elements from target material in shorter amount of time compared to the conventional methods ${ }^{12-13}$. It allows supercritical operations at relatively low pressure and near room temperature, thus producing extracts/compounds which remain in chemically natural state. The extracts are typically sterilized, free from contamination and solvent free ${ }^{13}$.

The only drawbacks of SFE are the higher initial investment cost of the equipment ${ }^{15-16}$ and difficulty when used routinely since the extraction condition is highly dependence on the sample ${ }^{12}$.

In the present study, S. zalacca was subjected to extraction by steam distillation, solvent extraction and supercritical fluid extraction methods. The efficiency and percentage yields of these extracts were compared. 


\section{MATERIAL AND METHODS}

\section{Materials}

Salacca zalacca (Gaertn.) Voss were collected from Kampung Raja, Besut, Terengganu at their mature stage (5.5-6 months after pollination). The fruits were transported to Kuantan and were utilized immediately upon arrival. The preservation temperature was $37^{\circ} \mathrm{C}$. The plant was authenticated by Dr. Shamsul Khamis, a botanist from Universiti Kebangsaan Malaysia Herbarium (UKMB). A voucher specimen with voucher number PIIUM 0269-3 [VS-5] was deposited at the Herbarium of Kulliyyah of Pharmacy, International Islamic University Malaysia, Kuantan.

Analytical grade hexane (purity $98.7 \%$ ), dichloromethane (purity 99.99\%) and sodium sulfate anhydrous were purchased from Fisher Scientific (UK). Analytical grade diethyl ether (purity 99.5\%) was purchased from HmbG Chemicals (Germany).

\section{Sample preparation}

A $35 \mathrm{~kg}$ of fresh Salacca zalacca was collected from the seller in Kg. Raja, Terengganu, Malaysia. The fruits were sorted out, whereby the infected or spoiled fruits were thrown away leaving $20 \mathrm{~kg}$ of healthy and uninfected fruits. The fruits' thorns were removed before they were thoroughly washed to remove dirt and dried at room temperature. After that, the skin, flesh and seed parts were separated manually. The flesh was cut into small pieces before stored in air tight container and stored in $-20^{\circ} \mathrm{C}$ freezer for further extraction. A $20 \mathrm{~kg}$ of Salacca zalacca, produced approximately $8 \mathrm{~kg}$ of fruit flesh.

The flesh samples for supercritical fluid extraction (SFE) method was subjected to freezedrying (Martin Christ, Alpha 1-2 LDplus). The freezedrying method was adopted from N. N (2015) ${ }^{16}$. The flesh samples were stored in $-80^{\circ} \mathrm{C}$ freezer for overnight (12 hours) before freeze- dried for seven days to remove moisture content. The mouth of container was wrapped with needle-poked aluminum foil to avoid loss of sample during the process.

The dried samples were ground into smaller sizes before their moisture contents (\% MC) were determined by using halogen moisture analyzer (Mettler Toledo, HB43-S). A $3 \mathrm{~g}$ of dried samples were subjected for moisture content analyzer and repeated for five times to get the average value. The \% MC was expressed as the percentage of ratio of the mass of humid material minus the mass of the dried material over the humid material. The average \%MC for the dried Salacca zalacca samples was $-3.51 \% \pm 0.65(\mathrm{w} / \mathrm{w})$. The dried samples were stored in an air tight opaque container and kept in $2^{\circ} \mathrm{C}$ refrigerator up to extraction.

\section{Steam distillation}

Steam distillation using a simple laboratory quick fit apparatus based on Conde-Hernandez, Espinosa-Victoria, Trejo, and Beltran ${ }^{17}$. The distillation apparatus was assembled as Fig. 3 below. A 5000 $\mathrm{mL}$ round bottom boiling flask was used as the steam generator flask connecting to the $5000 \mathrm{~mL}$ biomass flask. A heating mantle was used as the heat source. A $100 \mathrm{ml}$ separatory funnel with Teflon valve was used as receiver.

The steam generator flask was filled with approximately $2500 \mathrm{~mL}$ water and heated with a heating mantle. A $3 \mathrm{~kg}$ of flesh sample was added into the biomass flask and subjected to steam distillation. As water vaporized, the steam passed through the biomass flask containing the plant material. The vapour passed through the cooled tube, where it was condensed. If the water level drops in the flask, small volumes of water (roughly $300 \mathrm{~mL}$ ) were added into the steam generator flask. Small amounts of water were added to prevent drastic drop in temperature. The heat should be kept at low and steady level. In this experiment, the temperature of heating mantle was set at $325^{\circ} \mathrm{C}$.

The distillate was collected into the receiving flask. The steam distillation process was conducted for $7 \mathrm{~h}$ until oil was no longer produced. The duration of steam distillation was recorded. The water layer was collected into storage bottle while the oil layer was collected into a beaker. After dehydrated by anhydrous sodium sulphate, the oil was transferred into amber vials. The experiment was repeated for another two times with a fresh new flesh sample each.

The oils extracted from the three experiments were weighed and the percentage yields were calculated using the formula in Equation 1. Percentage yield can be defined as the recovery of essential oil (as a percentage) from fresh or dry 
biomass of aromatic plant ${ }^{18}$. After that, the average percentage yield was calculated. The containers were properly sealed. The oil vials were stored in the refrigerator for further analysis.

$$
\text { Percentage yield }(\%)=\frac{\text { Weight of oil }(\mathrm{g})}{\text { Weight of salak flesh sample }(\mathrm{g})} \times 100 \%
$$

\section{Consecutive solvent extraction method}

A $200 \mathrm{~g}$ of sample was cold macerated in $200 \mathrm{~mL}$ hexane and left at room temperature for two days (Fig. 4). After two days, the extract was filtered through a filter paper (Whatman No. 1). The procedures were repeated for another two times to give a total extraction period of six days. The three extracts were then combined and concentrated by rotary evaporator to roughly $10 \mathrm{~mL}$ before dehydrated with anhydrous sodium sulphate. The extract was rotary evaporated again until all the chemicals were removed. The extract was weighed before $2 \mathrm{~mL}$ of extraction solvent was added to rinse off the extract from the rotary flask into the amber vial. The percentage yield was calculated, and the concentrated extract was stored in $4^{\circ} \mathrm{C}$ refrigerator for further analysis.

The residues from the filtration process were left to complete dryness in room temperature before proceeding to another maceration with solvents of higher polarity (diethyl ether and dichloromethane (DCM). By using the same procedures, the sample was consecutively extracted and concentrated with diethyl ether and DCM.

\section{Supercritical fluid extraction (SFE) method}

The supercritical carbon dioxide was carried out using supercritical fluid machine (SFT150 SFE System) in University Malaysia Pahang, Gambang, Pahang, Malaysia. The extraction vessel was a $1 \mathrm{~L}$ stainless steel vessel. Supercritical fluid extraction was conducted at pressures of $10 \mathrm{MPa}$, $25 \mathrm{MPa}$ and $40 \mathrm{MPa}$ and temperatures of $30^{\circ} \mathrm{C}$, $50^{\circ} \mathrm{C}$ and $70^{\circ} \mathrm{C}$ respectively. These conditions were chosen since they were the middle condition, and upper and lower extreme conditions of the actual experimental design. Each condition was conducted twice to find the average yield. The carbon dioxide flow rate was kept constant at $10 \mathrm{ml} /$ minute.

Plant sample (68 g) was divided into 2-3 parts and wrapped in muslin cloth before placed into the extraction vessel. Each supercritical extraction experiment was carried out for two hours static time followed by 20 min dynamic. The supercritical carbon dioxide was decompressed to the atmospheric pressure, lost its supercritical fluid properties, hence allowing the extract to be trapped in an internal trap container. The extract was then rinsed off into a vial with roughly $8 \mathrm{~mL}$ of diethyl ether. Since water layer was also present in the extract, it was dehydrated with anhydrous sodium sulphate before concentrated with rotary evaporator. The oil collected was weighed before $2 \mathrm{~mL}$ of diethyl ether was added to rinse off the oil extract from the rotary flask into an amber vial. The percentage yield was then calculated through following diagram steps.

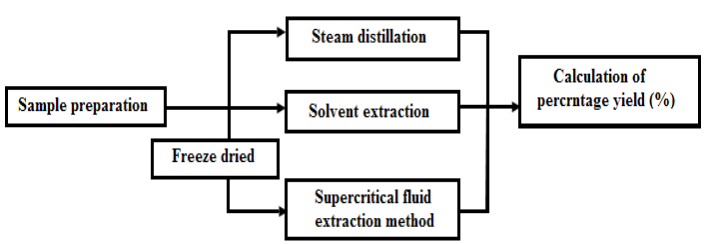

\section{RESULTS AND DISCUSSIONS}

\section{Steam distillation}

The percentage yield for each steam distillation process is shown in Table 1. The percentage yield for SD1, SD2, and SD3 were approximately $0.13 \%, 0.19 \%$, and $0.23 \%$ respectively. All three extracts were within the range of the yield of essential oils extracted using distillation mentioned by Chemat and Boutekedjiret ${ }^{19}$, where by, the yield of essential oils from plants using distillation was generally between 0.005 and $10 \%$. All extracts were also insoluble in water, colourless and have very mild sweet fruity smell. Due to these characteristics, it was assumed that the extracts collected were essential oils since essential oils are lipophilic and mostly colourless ${ }^{19}$.

There are four main factors that can affect the steam distillation yield ${ }^{19}$. These factors are the length of distillation time, the temperature, the operating pressure and most importantly, the type and quality of the plant material.

In this study, it was assumed that the temperature and pressure were not affecting the yield since they were kept constant for all three distillations. The water for the distillations were heated at $325^{\circ} \mathrm{C}$ to create a steam pressure for the steam distillation process. The duration of distillation was kept constant at $7 \mathrm{~h}$, while the plant material for all three distillations were collected from the same 
location at the same harvesting time. The only study on the distillation of $S$. zalacca was done by Wong and $\mathrm{Tie}^{8}$ whereby the volatile aroma of $S$. zalacca was extracted by simultaneous steam distillationextraction for 4 hours.

Study by Bozovic, Navarra, Garzoli, Pepi, \& Ragno ${ }^{21}$ revoked the classical theoretical believe that the distillation procedure was usually reported to be over in 2-4 hours. The study found that there was no rule about appropriate extraction time, and different plants need different periods for the essential oils to achieve the desired quality or quantity of extract. Thus, extraction duration was directly dependent on the purpose of study. In addition, harvesting period was found to be a major factor which directly affects the yield, extraction time and oil compositions.

Table 1: Colour, odour and percentage yield of steam distillation extracts

\begin{tabular}{lccc}
\hline Sample & SD1 & SD2 & SD3 \\
\hline Colour of extract collected & Colorless & Colorless & Colorless \\
Odour of oil collected & Mild sweet fruity smell & Mild sweet fruity smell & Mild sweet fruity smell \\
Percentage yield $(\%)$ & $\frac{4.0281 \mathrm{~g} \times 100 \%}{(3000 \mathrm{~g})}$ & $\frac{5.6626 \mathrm{~g} \times 100 \%}{(3000 \mathrm{~g})}$ & $\frac{7.0041 \mathrm{~g} \times 100 \%}{3000 \mathrm{~g}}$ \\
& $=0.1343$ & $=0.1888$ & $=0.2335$ \\
Average percentage yield $(\%)$ & & 0.1855 & \\
\hline
\end{tabular}

Note. SD1 = Steam distillation 1, SD2= Steam distillation 2, SD3= Steam distillation 3

\section{Consecutive solvent extraction}

Different solvents with different polarities were used to determine the solvent that will give the highest recoveries of volatile aroma compounds. The solvents used were hexane, diethyl ether, and DCM. The extraction duration was six days for each solvent. It was observed that all three solvents were able to extract certain degree of volatile aroma based on the odor of extract. The colour, odour, and percentage yield for each solvent was presented in Table 2. Based on the obtained result, the highest percentage yield was found with diethyl ether (DEE) extraction $(0.5692 \%)$ followed by DCM $(0.1358 \%)$ and hexane $(0.0511 \%)$.

Hexane was selected as one of the extraction solvent since it has the nearest polarity to pentane used by Wong and $\mathrm{Tie}^{8}$ for the extraction of volatile constituents of $S$. zalacca. The yield of total volatiles extracted by pentane was estimated to be 41 $\mathrm{mg} / \mathrm{kg}^{8}$. Diethyl ether were also used for the extraction of $S$. zalacca ${ }^{22}$. These studies did not determine the percentage yield of total extract of the fruit. However, Supriyadi et al., ${ }^{22}$ reported that diethyl ether was a better solvent for extracting volatile aroma of $S$. zalacca as it can extract almost double of the total number of volatile compounds extracted by pentane done by Wong and $\mathrm{Tie}^{8}$. On the other hand, there were no reports available on the use of hexane and DCM for the extraction of volatile aroma of S.zalacca. However, dichloromethane was one of the commonly used extraction solvent for aroma compounds since it was considered as an efficient solvent for the isolation of volatile compounds in fruits and plants ${ }^{23}$.

\section{Supercritical fluid extraction}

The percentage yields of SFE runs were calculated on the basis of dry weight. It was observed that the average percentage yield for all conditions were near to each other (Table 3). Nevertheless, the condition which produced the highest yield was Run 3 with the average percentage yield of $0.2721 \%$ compared to Run 1 and Run 2 with average percentage yields of $0.2577 \%$ and $0.2375 \%$ respectively.

It is important to note that analysis of volatiles from either intact or disrupted fruit tissues will affect the aroma profiles and final aroma interpretation ${ }^{4}$. The extraction yield can be increased by decreasing the size of sample particle. Higher amount of oil will be released as the bud cells are destroyed by milling and the aroma compounds are unbounded from the sugar moiety ${ }^{24}$. The direct exposure of these oils to the supercritical carbon dioxide allows maximal extraction of oil from plant sample. In addition, shorter diffusion paths in the milled solid matrix resulted in smaller intraparticle resistance to diffusion. However, to avoid co-extraction of compounds with high molecular weight, especially if the aim of research is to extract volatile compounds, the particle size should not be too small ${ }^{25}$.

Even though the average percentage yields were similar, the extracted compounds for each condition may differ from each other. This is because the density of carbon dioxide can be continuously 
adjusted by changing the pressure and temperature, analysis can be conducted in the future to compare resulting in highly selective extraction ${ }^{12}$. The GC/MS the compounds extracted by each condition.

Table 2: Colour, odour and percentage yield of extracts obtained from hexane, diethyl ether and DCM

\begin{tabular}{|c|c|c|c|c|c|c|c|c|c|}
\hline \multirow{2}{*}{$\begin{array}{l}\text { Sample } \\
\text { Run }\end{array}$} & \multicolumn{3}{|c|}{ Hexane } & \multicolumn{3}{|c|}{ Diethyl ether (DEE) } & \multicolumn{3}{|c|}{ DCM } \\
\hline & 1 & 2 & 3 & 1 & 2 & 3 & 1 & 2 & 3 \\
\hline $\begin{array}{l}\text { Weight of empty } \\
\text { rotary flask (g) }\end{array}$ & 115.253 & 115.250 & 115.258 & \multicolumn{6}{|c|}{ rotary flask (g) } \\
\hline $\begin{array}{l}\text { Weight of rotary } \\
\text { flask + extract } \\
\text { before rotavep }(\mathrm{g})\end{array}$ & 121.628 & 120.355 & 119.8335 & 125.7990 & 133.8454 & 129.4277 & 121.1191 & 141.7452 & 137.7231 \\
\hline \multicolumn{10}{|l|}{$\begin{array}{l}\text { flask + extract } \\
\text { after rotavep }(\mathrm{g})\end{array}$} \\
\hline $\begin{array}{l}\text { Weight of extract } \\
\text { collected }(\mathrm{g})\end{array}$ & 0.050 & 0.102 & 0.153 & 0.4536 & 1.2849 & 1.6764 & 0.2239 & 0.2711 & 0.3198 \\
\hline $\begin{array}{l}\text { Percentage } \\
\text { yield(\%) }\end{array}$ & 0.025 & 0.051 & 0.076 & 0.2268 & 0.6425 & 0.8382 & 0.1120 & 0.1356 & 0.1599 \\
\hline $\begin{array}{l}\text { Average percentage } \\
\text { yield }(\%)\end{array}$ & \multicolumn{3}{|c|}{0.051} & \multicolumn{3}{|c|}{0.569} & \multicolumn{3}{|c|}{0.136} \\
\hline Color and odour & \multicolumn{3}{|c|}{$\begin{array}{l}\text { Colorless with sweet fruity } \\
\text { smell and slight } \\
\text { solvent smell }\end{array}$} & \multicolumn{3}{|c|}{$\begin{array}{l}\text { Yellow with slight sweet fruity } \\
\text { smell and strong } \\
\text { solvent smell }\end{array}$} & \multicolumn{3}{|c|}{$\begin{array}{c}\text { Yellow with slight sweet fruity } \\
\text { smell and strong } \\
\text { solvent smell }\end{array}$} \\
\hline
\end{tabular}

The plant samples were crushed into smallest size possible instead of grinded with a grinder before wrapped in muslin cloth before subjected to extraction. Since the samples particle size was considerably coarse, the static time was set longer to allow deep penetration of solvent into the sample matrix. The high diffusivity of supercritical carbon dioxide was used to access the plant matrix whereby the cell swelling causes the breakdown of cellular structures allowing for contact between the solute and solvent ${ }^{26}$. Unfortunately, there was high possibility that the extraction was incomplete.

\section{Comparison between conventional and non-conventional extraction methods}

The efficiency of extraction methods in the present study was evaluated based on the extract recovery, duration of extraction and amount of toxic chemical waste produced. Steam distillation and solvent extractions were the chosen consecutive extraction methods while SFE was the chosen non-consecutive extraction method.

Based on Table 4, diethyl ether (DEE) solvent extraction $(0.5692 \%)$ has the highest average percentage yield followed by SFE $(0.2721 \%)$, steam distillation $(0.1855 \%)$, DCM solvent extraction $(0.1358 \%)$ and hexane $(0.0511 \%)$ solvent extraction respectively.

Regardless if condition, SFE produced higher yield at a shorter extraction period compared to steam distillation. It produced an average of approximately $0.265 \%$ yield (odor less) in just $2.3 \mathrm{~h}$ while steam distillation produced an average of $0.190 \%$ yield in seven hours. Solvent extraction was the least efficient as it took six days only to produced yields which were less than $1.00 \%$. Furthermore, solvent extractions consumed large amount of chemicals compared to the other methods. The procurement of solvents and the management of chemical wastes are costly.

Many previous research showed similar result. Study by Khajeh, Yamini, and Shariati ${ }^{27}$ found that regardless of conditions, SFE produced higher essential oil yield of Nepeta persica with lesser amount of sample and shorter extraction time in comparison to steam distillation. On the other hand, Wenqiang et al., ${ }^{25}$ proved that solvent extraction using soxhlet apparatus produced the highest clove essential oil compared to steam distillation and SFE. However, the solvent extraction method had longer extraction period than the Supercritical fluid extraction. 
Table 3: Colour, odour and percentage yield of extracts obtained from three conditions of supercritical carbon dioxide method

\begin{tabular}{|c|c|c|c|c|c|c|}
\hline \multirow{2}{*}{$\begin{array}{l}\text { Run } \\
\text { Condition } \\
\text { Sample }\end{array}$} & \multicolumn{2}{|c|}{$\begin{array}{c}\text { RUN } 1 \\
10 \mathrm{MPa}, 30^{\circ} \mathrm{C}\end{array}$} & \multicolumn{2}{|c|}{$\begin{array}{c}\text { RUN } 2 \\
25 \mathrm{MPa}, 50^{\circ} \mathrm{C}\end{array}$} & \multicolumn{2}{|c|}{$\begin{array}{c}\text { RUN } 3 \\
40 \mathrm{MPa}, 70^{\circ} \mathrm{C}\end{array}$} \\
\hline & 1 & 2 & 1 & 2 & 1 & 2 \\
\hline Moisture content (\%) & -3.57 & 3.99 & -2.69 & -4.26 & 3.99 & -3.06 \\
\hline Weight of dried sample (g) & 65.57 & 65.29 & 66.17 & 65.1 & 65.29 & 65.92 \\
\hline Weight of empty rotary flask (g) & 114.038 & 121.620 & 115.141 & 115.407 & 121.5952 & 113.938 \\
\hline Weight of rotary flask + extract after rotated $(\mathrm{g})$ & 114.200 & 121.795 & 115.304 & 115.586 & 121.7840 & 114.096 \\
\hline Weight of extract collected (g) & 0.162 & 0.175 & 0.163 & 0.179 & 0.1888 & 0.168 \\
\hline Percentage yield (\%) & 0.2471 & 0.2682 & 0.2472 & 0.2689 & 0.2892 & 0.2549 \\
\hline Average percentage yield (\%) & \multicolumn{2}{|c|}{0.2577} & \multicolumn{2}{|c|}{0.2680} & \multicolumn{2}{|c|}{0.2721} \\
\hline Color and odour & $\begin{array}{l}\text { Pale yellow } \\
\text { with slight } \\
\text { fruity smell }\end{array}$ & $\begin{array}{l}\text { Pale yellow } \\
\text { with slight } \\
\text { fruity smell }\end{array}$ & $\begin{array}{l}\text { Yellow with } \\
\text { fruity smell }\end{array}$ & $\begin{array}{l}\text { Yellow with } \\
\text { fruity smell }\end{array}$ & $\begin{array}{l}\text { Yellow with } \\
\text { fruity smell }\end{array}$ & $\begin{array}{l}\text { Yellow with } \\
\text { fruity smell }\end{array}$ \\
\hline
\end{tabular}

Sum up, SFE is a green technology as it produced very little chemical waste. In current study, the chemical solvent $\mathrm{CO}_{2}$ was used in the SFE to collect the extract from the trapping container. SFE is also very efficient as it produced high amount of extract with little amount of sample and shorter extraction period. On the other hand, solvent extraction (ME) method is inefficient compared to the SFE as it required a very long extraction period and yield is mixture of solvent and extract. Solvent extraction also produced a lot of toxic chemical waste.

Table 4: Comparison between consecutive and non-consecutive extraction methods

\begin{tabular}{|c|c|c|c|c|c|c|c|}
\hline \multirow[b]{2}{*}{ Extraction methods } & \multicolumn{3}{|c|}{ Consecutive extraction method } & & \multirow{2}{*}{\multicolumn{3}{|c|}{$\begin{array}{l}\text { Non- consecutive extraction method } \\
\text { SFE }\end{array}$}} \\
\hline & $\begin{array}{c}\text { Steam } \\
\text { distillation }\end{array}$ & & olvent extractic & & & & \\
\hline Solvent/Condition & - & Hexane & Diethyl Ether & DCM 1 & $10 \mathrm{MPA}, 30^{\circ} \mathrm{C}$ & $25 \mathrm{MPA}, 50^{\circ} \mathrm{C}$ & $40 \mathrm{MPA}, 70^{\circ} \mathrm{C}$ \\
\hline Amount of samples (g) & 3000 & 200 & 200 & 200 & 68 & 68 & 68 \\
\hline Amount of chemical waste $(\mathrm{mL})$ & - & 600 & 600 & 600 & 2 & 2 & 2 \\
\hline Duration of extraction (hours) & 7 & 144 (6 days) & 144 (6 days) & 144 (6 days) & 2.3 & 2.3 & 2.3 \\
\hline Average percentage yield (\%) & 0.1855 & 0.0511 & 0.5692 & 0.1358 & 0.2577 & 0.2680 & 0.2721 \\
\hline
\end{tabular}

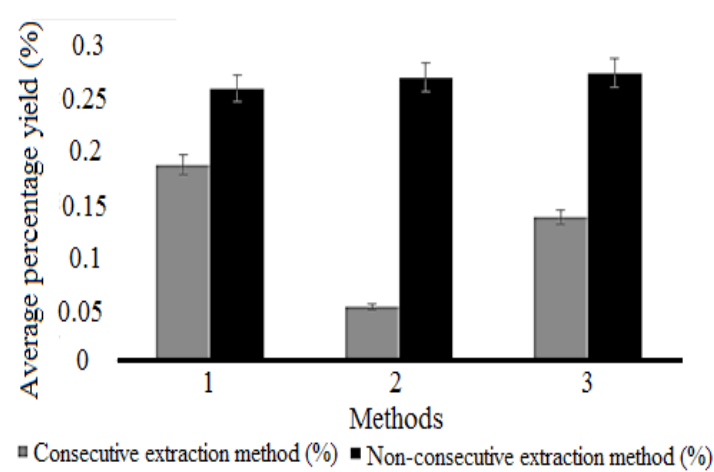

Fig. 1. Evaluation of average percentage yield (\%) between consecutive and non-consecutive extraction methods

SFE was proven to have better selectivity and capability to produce extracts of higher purity and quality compared to steam distillation and solvent extraction (Fig. 1) ${ }^{15}$. The GC/MS analysis can be done in the future to identify and compare the volatile aroma constituents obtained from these methods.

SFE method will give relatively less amount of aroma compounds compared to the solvent extraction (DEE) method but we obtained pure aroma compounds due to used solvent was carbon dioxide gas $\left(\mathrm{CO}_{2}\right)$.

To the best of our knowledge, no studies had compared the extraction methods of volatile compounds of this plant species. Supercritical fluid extraction method showed great potential in the extraction of non-polar volatile compounds from S. zalacca. Supercritical fluid extraction (SFE) is the more efficient and environmental friendly technique, Compared to the non-conventional steam distillation and solvent extraction methods.

There were some limitations faced during the study. Some of the volatile aroma compounds in both solvent extraction and SFE extracts might have lost during the concentrating process and storage. All solvents used in recent study were highly volatile solvents. It was difficult to preserve the actual amount of solvents in a container as they were easily evaporated. To minimize the loss of volatile solvents, 
the amber vial was properly sealed and stored in $4^{\circ} \mathrm{C}$ refrigerator.

Finally, salak fruit is a seasonal fruit in Malaysia. So, it was quite difficult to obtain large amount of fruit sample out of the season. There is high possibility that the fruits purchased outside its season contain different volatile constituents than those purchased during its season.

To overcome the problem, salak fruits were bought in bulk from the same orchard, at the same season and maturity stage. The fruits were then stored in $-20^{\circ} \mathrm{C}$ freezer until further use to preserve the compounds contained in the fruits.

\section{CONCLUSION}

The use of green technology for the environmentally friendly extraction of volatile aroma of Salacca zalacca cultivated in Malaysia was the great achievement of this study. SFE was found to be more efficient and environmental friendly compared to the conventional steam distillation and consecutive solvent extraction methods. SFE required lesser amount of sample and shorter extraction time to produce satisfactory amount of extract. Diethyl ether solvent extraction produced the highest percentage yield followed by SFE (regardless of conditions), steam distillation, DCM solvent extraction and hexane solvent extraction respectively. SFE has the shortest extraction time, did not consume any chemical solvent and required lesser amount of sample to produce satisfactory amount of extract.

SFE is considered as a green extraction technique because it is renewable, produces little to no toxic wastes and has short extraction time

\section{ACKNOWLEDGEMENT}

The authors would like to express our appreciation to International Islamic University Malaysia (IIUM) for providing financial supports via grant (FRGS16- 042-0541) to complete the research. Huge amount of gratitude to lab mates, science officer, laboratory assisstants and technicians in Kulliyyah of Pharmacy, Kulliyyah of Science (IIUM) UMT and UMP for their insightful ideas, suggestion and technical support in this research. Finally, highest gratitude to family members and friends for their support, love, understanding and encouragement throughout the research work.

\section{Conflict of Interest}

The authors declare no conflict of interest.

\section{REFERENCES}

1. Supapvanich, S., Megia, R., \& Ding, P. Salak (Salacca zalacca (Gaertner) Voss). In Postharvest biology and technology of tropical and subtropical fruits. Woodhead Publishing Limited., 2011, 334-352.

2. Cagliero, C., Sgorbini, B., Cordero, C., Liberto, E., Bicchi, C., \& Rubiolo, P. Analytical strategies for multipurpose studies of a plant volatile fraction. In K. Hostettmann, S. Chen, A. Marston, \& H. Stuppner (Eds.), Handbook of chemical and biological plant analytical methods-volume 2, West Sussex, United Kingdom: John Wiley \& Sons Ltd., 2014, 447-466.

3. Forney, C. F.. Physiology and biochemistry of aroma and off-odors in fresh-cut products. Acta Horti., 2016, 1141, 35-46.

4. Hadi, M. A. M. El, Zhang, F.-J., Wu, F.-F., Zhou, C.-H., \& Tao, J. Advances in fruit aroma volatile research. Mole., 2013. 18, 8200-8229.

5. Simmonds, M. S. J. Selection, identification and collection of plants. In S. Chen, A. Marston, \& H. Stuppner (Eds.), Handbook of chemical and biological plant analytical methods-volume 1 (1st ed.). West Sussex, UK: Joh Wiley \& Sons Ltd., 2014. 3-16.

6. Supriyadi, Suhardi, Suzuki, M., Yoshida, K., Muto, T., Fujita, A., \& Watanabe, N. Changes in the volatile compounds and in the chemical and physical properties of snake fruit (Salacca edulis Reinw ) cv. Pondoh during maturation. J. Agri. Food Chem., 2002. 50, 7627-7633.

7. Wijaya, C. H., Ulrich, D., Lestari, R., Schippel, K., \& Ebert, G. Identification of potent odorants in different cultivars of snake fruit [Salacca zalacca (Gaert.) Voss] using gas chromatography-olfactometry. J. Agri. Food Chem., 2005, 53(5), 1637-1641.

8. Wong, K. C., \& Tie, D. Y. . Volatile constituents of salak (Salacca edulis Reinw.) fruit. Flavour and Fragrance Journal., 1993, 8, 321-324.

9. Lubes, G., \& Goodarzi, M. Analysis of volatile compounds by advanced analytical techniques and multivariate chemometrics. Chemical Reviews., 2017, 117, 6399-6422. 
10. Chun-ping, X., Shanshan, Z., Yuanshang, L., Ying, Z., \& Hui, H. Chemical composition and comparison of the Rehmannia glutinosa Libosch oil using steam distillation and solvent extraction. Journal of Biologically Active Products from Nature., 2016, 6(1), 25-31.

11. Andrade, B. F. M. T., Barbosa, L. N., Probst, I. da S., \& Junior, A. F. Antimicrobial activity of essential oils. Journal of Essential Oil Research., 2014, 26(1), 34-40.

12. Camel, V. Extraction methodologies. In K. Hostettmann, S. Chen, A. Marston, \& H. Stuppner (Eds.), Handbook of chemical and biological plant analytical methods-volume 1 (1st ed., pp. 17-42). West Sussex, UK: Joh Wiley \& Sons Ltd., 2014.

13. Akanda, M. J. H., Sarker, M. Z. I., Ferdosh, S., Manap, M. Y. A., Rahman, N. N. N. A., \& Kadir, M. O. A. Applications of supercritical fluid extraction (SFE) of palm oil and oil from natural sources. Molecules., 2012, 17(2), 1764-1794.

14. Pourmortazavi, S. M., Rahimi-Nasrabadi, M., \& Mirsadeghi, S. Supercritical fluid extraction. In S. Chen, A. Marston, \& H. Stuppner (Eds.), Handbook of chemical and biological plant analytical methods West Sussex, UK: John Wiley \& Sons Ltd., 2014, 1(1), 43-76).

15. Zermane, A., Larkeche, O., Meniai, A. H., Crampon, C., \& Badens, E.. Optimization of Algerian rosemary essential oil extraction yield by supercritical $\mathrm{CO}_{2}$ using response surface methodology. Comptes Rendus Chimie., 2016, 1-6.

16. N. N, A. A Review on the extraction methods use in medicinal plants, principle, strength and limitation. Medicinal \& Aromatic Plants., 2015, 4(3), 1-6.

17. Conde-Hernandez, L. A., Espinosa-Victoria, J. R., Trejo, A., \& Beltran, J. A. G. $\mathrm{CO}_{2}$ -supercritical extraction, hydrodistillation and steam distillation of essential oil of rosemary (Rosmarinus officinalis). Journal of Food Engineering., 2017, 200, 81-86.

18. Ikya, J. K., Umenger, L. N., \& lorbee, A. Effects of extraction methods on the yield and quality characteristics of oils from shea nut. Journal of Food Resource Science., 2013, 2(1), 1-12.

19. Chemat, F., \& Boutekedjiret, C. Extraction// steam distillation. In Reference module in chemistry, Molecular Sciences and Chemical Engineering., 2015, 1-12, Elsevier B.V.

20. Turek, C., \& Stintzing, F. C. Stability of essential oils : A review. Comprehensive Reviews in Food Science and Food Safety., 2013, 12, 40-53.

21. Supriyadi, Suzuki, M., Wu, S., Tomita, N., Fujita, A., \& Watanabe, N. Biogenesis of volatile methyl esters in snake fruit (Salacca edulis Reinw) cv. Pondoh. Bioscience, Biotechnology, and Biochemistry., 2003, 67(6), 1267-1271.

22. Bozovic, M., Navarra, A., Garzoli, S., Pepi, F., \& Ragno, R. Esential oils extraction: A 24-hour steam distillation systematic methodology. Natural Product Research., 2017, 31(20), 2387-2396.

23. Amanpour, A., Sonmezdag, A.S., Kelebek, H., \& Selli, S. GC-MS-olfactometric characterization of the most aroma-active components in a representative aromatic extract from Iranian saffron (Crocus sativus L.). Food Chemistry., 2015, 182, 251-256.

24. Reverchon, E. Mathematical modeling of supercritical extraction of sage oil. AlChe Journal., 1996, 42(6), 1765-1771.

25. Wenqiang, G., Shufen, L., Ruixiang, Y., Shaokun, T., \& Can, Q. Comparison of essential oils of clove buds extracted with supercritical carbon dioxide and other three traditional extraction methods. Food Chemistry., 2007, 101, 1558-1564.

26. Cavalcanti, R. N., \& Meireles, M. A. A. Fundamentals of supercritical fluid extraction. In Comprehensive Sampling and Sample Preparation. Elsevier Inc., 2012, 2, 117-133.

27. Khajeh, M., Yamini, Y., \& Shariati, S. Comparison of essential oils compositions of Nepeta persica obtained by supercritical carbon dioxide extraction and steam distillation methods. Food and Bioproducts Processing., 2010, 88(2-3), 227-232. 